\title{
THE CONCEPT OF AL-MAU'IZAT AND ITS RELEVANCE IN ISLAMIC EDUCATION
}

\section{KONSEP AL-MAU'IZAT DAN RELEVANSINYA DALAM PENDIDIKAN ISLAM}

\author{
Achyar Zein', Syamsu Nahar', Muhammad Fajri Syahroni Siregar ${ }^{3}$, Rahmadi Ali ${ }^{4}$ \\ 1,2,3 Pascasarjana Universitas Islam Negeri Sumatera Utara \\ ${ }^{4}$ Universitas Muslim Nusantara Al Washliyah Medan \\ email: achyarzein@gmail.com \\ email: syamsunahar.edu@gmail.com \\ email: syahronisiregar1404@gmail.com \\ email: rahmadi.ali2121@gmail.com
}

\section{Received: 15/07/2020, Accepted: 25/08/2020, Published: 29/08/2020}

\begin{abstract}
Al-Mau'izat is one of the methods used in learning Islamic education. The purpose of this research is to know the concept of al-Mau'izat in the Koran and explain how the relevance of the concept of al-Mau'izat in Islamic education is expected to add insight into Islamic education. Research by the author is including qualitative research and when collecting data using descriptive and Mawdhu'i methods. The results of this study will be collected and analyzed data and look for relevance in Islamic education. This data will be presented in the descriptive form in the form of sentences. The conclusion is that al-Mau'izat is a method that is interpreted as advice used in Islamic Education, and al-mau'izat should be done in a kind and gentle manner.
\end{abstract}

Keywords: al-mau'izat, methods, Islamic education.

\begin{abstract}
ABSTRAK
Al-Mau'izat merupakan salah satu metode yang digunakan di dalam pembelajaran pendidikan Islam. Tujuan dilakukan penelitian ini, yaitu mengetahui konsep al-mau'izat di dalam Alquran dan menjelaskan bagaimana relevansi konsep al-mau'izat ini dalam pendidikan Islam yang diharapakan akan menambah wawasan terkait dengan Pendidikan Islam. Penelitian yang penulis lakukan ini adalah termasuk penelitian kualitatif dan saat mengumpulkan datanya menggunakan metode deskritptif dan metode mawdhu'i. Hasil penelitian ini datanya akan dikumpulkan dan dianalisis dan dicarilah relevansinya dalam pendidikan Islam. Data ini akan disajikan dalam bentuk deskriptif berupa kalimat-kalimat. Kesimpulannya bahwasannya Al-mau'izat merupakan metode yang dimaknai sebagai nasehat yang digunakan dalam Pendidikan Islam dan al-mau'izat ini seharusnya dilakukan dengan cara yang baik dan lemah lembut.
\end{abstract}

Kata kunci: al-mau'izat, metode, pendidikan Islam 


\section{A. PENDAHULUAN}

Pendidikan merupakan hal yang sangat penting untuk manusia karena pendidikan memiliki tujuan untuk meningkatkan kualitas hidup manusia. Pendidikan juga memiliki peran untuk menyiapkan manusia bisa berperan aktif di dalam lingkungannya. Akhirnya pun pendidikan diangggap sebagai sebuah alat untuk menciptakan generasi manusia yang pintar secara intelektual di bidang akademisi, namun juga berjalan sesuai dengan ketentuan yang telah ada di dalam agama dan juga pada lingkungann masyarakat.

Pada dasarnya, saat manusia terlahir ke dunia, manusia dikaruniai memiliki sifat yaitu sikap suka meniru sebagai naluri yang telah ada di dalam jiwa manusia naluri inilah yang mendorong manusia untuk meniru perilaku yang tgelah lebih dahulu dewasa, kuat dan mampu memimpin, sehingga manusia bisa menirukan hal-hal yang telah diperolehnya. Saat proses pendidikan itulah manusia bisa mendapatkan pengetahuan agar bisa ditirunya sehingga bisa diaplikasikan di dalam kehidupan sehari-hari.

Saat proses Pendidikan berlangsung, maka sangat dibutuhkan metode pembelajaran untuk dijadikan sebuah acuan yang baku dan sistematis dalam menyampaikan materi pelajaran. Metode pembelajaran harus dilakukan secara teratur dan tahap demi tahap dengan cara yang beragam untuk mencapai tujuan tertentu dibawah kondisi yang berbeda.

Metode pembelajaran ini memiliki fungsi terhadap guru, siswa disaat proses pembelajaran berlangsung. Bagi seorang guru, metode dalam pembelajaran berguna sebagai pedoman saat mengajarkan sebuah materi pelajaran kepada siswanya yang dilakukan dengan sistematis dalam pelaksanaan pembelajaran. Siswa pun juga mendapatkan keuntungan dari penggunaan metode pembelajaran ini, karena metode yang digunakan akan mempermudah proses pembelajaran di kelas dan mempercepat memahami isi materi pelajaran, Setiap metode dalam pembelajaran dirancang khusus untuk mempermudah segala proses pembelajaran.

Manusia sangat membutuhkan pendidikan dengan tujuan untuk mengetahui perbuatan yang baik dan buruk sehingga mampu menegakkan amar ma'ruf dan nahi mungkar. Manusia memang sangat membutuhkan pendidikan Islam dikarenakan memiliki tujuan mengajak sesamanya untuk beriman, berilmu dan beramal shaleh. Alquran telah menawarkan suatu cara agar manusia bisa menerima pengetahuan dan pelajaran yang disebut $a l$ mau'izat yang bermakna sebagai 
"pemberian nasehat" dan "perumpamaan yang menyentuh hati/jiwa sesuai dengan pengetahuan objeknya secara sederhana agar mudah untuk dipahami”.

Term al-mau'izat diambil dari kata memiliki makna الوعظ Kata و عظ - يعظ - وعظا sebagai nasehat yang diberikan untuk bisa menjelaskan sesuatu tentang kebaikan agar hal yang diberikan itu bisa menjadi lebih baik. Adapun al-mau'izat ini seharusnya disampaikan dengan baik.

Ar-Raghib berpendapat bahwa di dalam bukunya yang berjudul kamus Alquran, bahwa kata وعظ diartikan sebagai pembentakan yang disertai dengan menakut-nakuti. Namun al-Khalil berkata bahwa الوعظ yaitu penyebutan kebaikan yang dapat menyentuh hati. Adapun kata adalah isim.

Al-mau'izat memiliki beragam makna seperti yang dijelaskan dalam beberapa ayat Alquran yang dijadikan sebagai bentuk turunan dari al-mau'izat itu sendiri. Muhammad Fuad Abdul Baqi' mengungkapka terma al-mau'iz̧at yang ditemukan sebanyak 9 kali di berbagai surah, antara lain di dalam surah alBaqarah ayat 66 dan 275, surah Ali Imran ayat 138, surah al-Maidah ayat 46, surah alAraf ayat 145, surah Yunus ayat 57, surah Hud ayat 120, surah an-Nahl ayat 125, dan surah an-Nur ayat 34.
Term al-mau'izat memiliki beragam arti. Pertama, bermakna nasihat, yaitu sebuah kajian tentang kebenaran dengan maksud mengajak orang lain (yang dinasehati) untuk mengamalkannya. Nasihat yang baik itu harus bersumber dari Yang Maha Baik, yaitu Allah swt. Kedua, bermakna tadzkir (peringatan). Seseorang yang memberi nasehat hendaknya berulangkali mengingatkan agar nasihat itu meninggalkan kesan sehingga orang tersebut yang dinasihati tergerak untuk mengikuti nasehat itu.

Metode ini sangat efektif bila ucapan yang disampaikan itu disertai dengan pengalaman dan keteladanan dari orang yang menyampaikannya tentang kebaikan itu. Al-mau'izat juga memiliki tujuan untuk mencegah dari sesuatu yang buruk. Metode al-mau'izat ini dapat digunakan pada proses pendidikan Islam dikarenakan almau'izat cukup efektif dalam membentuk iman seorang anak dan bisa digunakan dalam mempersiapkan akhlak dan rasa sosialnya.

Saat berjalannya proses pendidikan, hal penting yang mendukung berjalannya proses itu adalah komunikasi yang efektif. Karena ketika membahas mengenai komunikasi, terdapat teori modern yang menjelaskan adanya sifat mulia yang disebut trust worthiness dan sifat ingin tahu 
dalam komunikasi disebut expertness. Orang yang tidak memiliki akhlak terpuji walaupun pengetahuannya sangat baik dan juga ia pun tidak memiliki integritas kepribadian, maka ia akan susah menjadi komunikator di dalam kehidupan, terutama saat berjalannya proses Pendidikan.

Ketika mendidik dan memberikan ilmu pengetahuan, seorang pendidik juga perlu untuk memperhatikan kondisi dan situasi dari peserta didik sehingga mereka tidak memiliki perasaan seakan-akan dipaksa dan juga pendidik mau menyampaikannya dengan santun sampai daun letaknya dianggap asyik. suasana dialogis bersifat manusiawi. Seorang pendidik seharusnya memiliki kemampuan untuk membimbing serta bisa menjadi teman dekat yang setia untuk orang yang dirinya juga memiliki sifat penyayang dan bisa melakukan hal-hal yang bermanfaat. Jika terpenuhi syaratsyarat ini, maka pendidik bisa menjadikan orang-orang yang tidak mencapai kemampuan akhirnya memiliki kemampuan.

Alquran menjelaskan bahwasanya nasehat itu diberikan dengan rasa kasih sayang, hari ini bisa dilihat di dalam Surah Luqman. Pada surah itu, Luqman memberikan nasehat dengan kasih sayang karena yang diberikan Luqman bebas dari celaan kata-kata yang tidak pantas. Luqman juga Tulus saat memberikan nasehat kepada anaknya. Saat model nasehat yang dilakukan Luqman bisa diterapkan pada proses Pendidikan, maka pendidik ataupun guru itu bisa menyentuh muridnya. Pendidik harus memiliki sifat yang Arif dan bijaksana agar nasehatnya dapat diterima hingga akhirnya diaplikasikan.

Bahwasannya nasehat yang dilakukan dengan kelemah-lembutan, pelan-pelan, di barengi juga dengan sikap penuh kasih sayang kepada orang yang diberi nasehat dan menghargainya, maka akan dapat membangkitkan perasaan hal-hal baik itu juga ada dalam dirinya peserta didik. Hal ini juga sesuai dengan pendapat dari Fadhullah bahwasannya manusia memiliki perasaan yang bisa disentuh jika adanya rasa cinta dan sayang yang diperlihatkan hingga mampu membangkitkan semangat untuk menjadi mukmin sejati setelah mendapatkan nasehat. Hal inilah yang menjadikan peneliti merasa bahwa konsep al-mau'izat dalam Alquran perlu diteliti dan juga mengetahui relevansinya dengan Pendidikan Islam.

\section{B. METODE PENELITIAN}

Pelitian ini menggunakan jenis penelitian library research (penelitian kepustakaan), yaitu sesuatu penelitian yang menggunakan buku-buku, dokumen, 
majalah dan surah kabar sebagai bahan acuan dalam penelitian. Sedangkan metode pembahasan yang penulis gunakan adalah metode deskriptif dan tafsir mawdhu'i. Metode deskriptif ini digunakan dalam menghimpun data dan fakta sehingga tergambarlah konsep al-mau'izat dalam Alquran. Sedangkan metode mawdhu'i digunakan dalam mencari nash-nash Alquran sehingga diperolehlah sebuah kesimpulan yang terang bagaiana almau'izat ini berkaitan dengan Pendidikan Islam. Adapun langkah-langkah yang digunakan dalam metode ini adalah:

1. Membahas atau menetapkan masalah yang akan dicari di dalam Alquran yang akan dikaji secara mawdhu'i Adapun tema yang peneliti cari di dalam Alquran ini yaitu tentang konsep al-mau'iz̧at dalam Alquran.

2. Kemudian peneliti mengumpulkan ayat-ayat Alquran yang terkait dengan al-mau'izat.

3. Mengetahui korelasi (munasabah) ayat-ayatnya.

4. Menyusun tema pembahasan di dalam kerangka yang pas dan sistematis.

5. Melengkapi pembahasan dengan hadis bila dipandang perlu, sehingga pembahasannya menjadi semakin sempurna dan juga jelas.
6. Mempelajari ayat-ayat tersebut secara tematik dan menyeluruh dengan cara menghimpun ayat-ayat yang mengandung pengertian serupa, sehingga semua ayat itu bertemu maknanya.

Adapun tahap-tahap yang akan peneliti lakukan dalam meneliti konsep al-mau'izat dalam Alquran adalah sebagai berikut.

1. Menetapkan masalah tentang konsep al-mau'izat dalam Alquran.

2. Menjelaskan ayat-ayat Alquran yang membicarakan masalah al-mau'izat.

3. Mengkaji sebab latar belakang turunnya ayat-ayat Alquran yang berkaita dengan al-mau'izat.

4. Menyusun pembahasan dalam kerangka yang sempurna.

5. Melengkapi pembahasan ini dengan hadis-hadis nabi saw.

Saat menjelaskan penelitian ini, penulis berharap agar ditemukannya konsep almau'izat dalam Alquran dengan menggunakan metode mawdhu'i. menurut pengertian istilah para ulama, bahwasannya metode tafsir mawdhu'i ini merupakan metode menafsirkan yang menghimpun seluruh ayat Alquran yang memiliki tujuan dan tema yang sama. Setelah itu disusun berdasarkan kronologis dari turunnya dengan memperhatikan sebab-sebab turunnya. Sehingga dapat dilanjutkan 
dengan menguraikannya agar mengetahui seluruh aspek yang dapat dipahami dari ayat-ayat yang menjelaskan tema tersebut. Metode tafsir mawdhu'i ini menjadi salah satu cara menafsirkan Alquran dengan menggunakan metode mengumpulkan sampai menyusun ayat-ayat Alquran yang sesuai dengan tema.

Pada penelitian ini juga terdapat sumber data yang merupakan bahan-bahan tulisan maupun bukan berbentuk tulisan. Karena sumber data memang harus ada di dalam sebuah penelitian. Pada penelitian kepustakaan ini (library research), sumber data merupakan bahan tertulis yang terdiri dari sumber data primer dan sekunder.

\section{Sumber data primer}

Sumber data primer yaitu data yang diperoleh langsung dari subyek penelitian sebagai sumber informasi yang dicari. Data ini disebut juga dengan data tangan pertama atau data yang langsung berkaitan dengan objek riset. Sumber data primer yang digunakan pada penelitian ini adalah Alquran dengan mencari ayat-ayat yang berkatan dengan al-mau'izat dalam Alquran

2. Sumber data sekunder

Data sekunder adalah data-data yang diperoleh lewat pihak lain yang menjadi pelengkap yang mendukung penelitian ini. Yang diambil dari berbagai literatur yang relevan dengan penelitian ini. Seperti tafsir al-Mishbah, al-Mu'jam al-Muhfarras li alFaz Alquran al-Karim, buku Kamus Alquran, buku-buku artikel ilmiah dan jurnal.

Bahwasannya penelitian ini memiliki empat ciri utama studi kepustakaan, pertama: peneliti berhadapan langsung dengan teks dan data angka dan bukannya dengan pengetahuan langsung dari lapangan atau saksi mata berupa kejadian, orang atau benda-benda lain. Kedua: data pustaka bersifat siap pakai. Ketiga: data pustaka umumnya adalah sumber sekunder yang bukan data orosinil dari tangan pertama di lapangan. Keempat: kondisi data pustaka tidak dibatasi oleh ruang dan waktu.

Adapun langkah-langkah yang akan penulis lakukan dalam pengumpulan data ini yaitu:

1. Mencari dan menyeleksi ayat-ayat dalam Alquran yang selaras dengan almau'izat dengan menggunakan buku al-Mu'jam al-Muhfarras li al- Faz Alquran al-Karim.

2. Mencari makna dari al-mau'izat di dalam kamus Alquran.

3. Mencari refrensi yag berkaitan dengan penelitian ini baik dari kitab-kitab, buku-buku yang membahas tentang penelitian ini. 
4. Mencari relevansi al-mau'izat dalam Pendidikan Islam.

Teknik analisis data yang digunakan dalam penelitian ini adalah analisis isi (content analysis) dan datanya termasuk data deskriptif. Data seperti ini sering dianalisis hanya dengan menurut kepada isinya.

Saat melakukan analisis data, maka langkah-langkah yang penulis lakukan adalah, Pertama, penulis menetapkan tema dari kata kunci yang akan dicari di dalam dokumen yang akan dikaji yaitu ayat-ayat yang berkaitan dengan al-mau'izat, Kedua, penulis memberikan makna atas tema tersebut, Ketiga, penulis menghubungkannya dengan Pendidikan Islam.

\section{PEMBAHASAN}

Term al-mau'izat antara lain terdapat surah al-Baqarah ayat 66 dan 275, surah Ali Imran ayat 138, surah al-Maidah ayat 46, surah al-Araf ayat 145, surah Yunus ayat 57, surah hud ayat 120, surah an-Nahl ayat 125 dan surah an-Nur ayat 34 .

\section{Al-Baqarah Ayat 66}

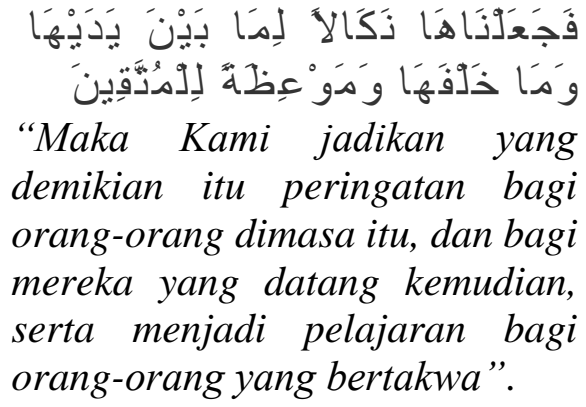

Menurut Tafsir al-Mishbah dijelaskan bahwa ayat ini menjelaskan tentang hari sabtu adalah hari yang telah ditetapkan Allah untuk orang Yahudi sesuai asal-usul mereka sebagai hari ibadah yang bebas dari aktivitas duniawi. Mereka dilarang mengail ikan pada hari itu. Akan tetapi, sebagian mereka melanggar dengan cara yang licik. Mereka tidak tidak mengail, tetapi membendung ikan dengan menggali kolam sehingga air bersama ikan masuk kekolam itu. Menurut sebagian mufassir berpendapat bahwa peristiwa ini terjadi di salah satu desa kota Aylah yang kini dikenal dengan teluk Aqabah. Kemudian setelah hari sabtu berlalu, mereka mengailnya.

Allah murka terhadap mereka, maka Allah berfirman kepada mereka, "Jadilah kamu kera yang hina terkutuk." Perintah ini bukan perintah kepada Bani Isra'il untuk mereka laksanakan, tetapi ini adalah taskhir, yakni perintah yang menghasilkan terjadinya sesuatu. Allah berfirman: "Sesuangguhnya perintah - Nya apabila Dia menghendaki susatu hanyalah berkata kepadanya, 'Jadilah', maka terjadilah Ia' (Q.S Yasin: 82)

Tafsir ini (al-Misbah) menjelaskan bahwasannya tidaklah jelas apakah bentuk rupa mereka yang diubah menjadi kera atau sifat, pikiran mereka saja yang seperti kera. 
Akan tetapi, kisah ini cukup populer di kalangan para pemuka agama mereka, sebagaimana diisyaratkan oleh ayat yang berbunyi "Sesungguhnya kalian telah mengetahui". Dalam ayat lain dijelaskan bahwa ada diantara mereka yang dijadikan kera dan babi (lihat QS. Al Maidah ayat 60). Apa yang terjadi terhadap mereka itu merupakan peringatan yang sangat berharga untuk dihindari, baik yang hidup ketika itu maupun generasi selanjutnya. Hal juga sekaligus menjadi pelajaran bagi orang-orang yang bertakwa.

Ibnu katsir menjelaskan di dalam tafsirnya bahwa yang dimaksud dengan almau'izat dalam ayat ini adalah peringatan keras. Makna dari ayat ini adalah kami jadikan siksa dan hukuman sebagai balasan atas pelanggaran mereka terhadap laranganlarangan Allah dan perbuatan mereka sebagai tipu muslihat.

Metode al-mau'izat pada ayat ini sangat tepat jika diterapkan dalam lembaga pendidikan, konsep ini diberikan agar mereka bisa taat pada peraturan yang telah ditetapkan, sehingga para siswa bisa mematuhi apa yang diperintahkan oleh guru, karena guru merupakan pendidik dalam ruang lingkup pendidikan, namun pendidik seluruh alam semesta ini ialah Allah Swt. Sehingga nasihat guru menjadi pembelajaran yang baik bagi mereka.
Dengan mematuhi apa yang diperintahkannya, maka akan menjadikan siswa yang taat pada peraturan.

\section{Surah Al-Baqarah Ayat 275}

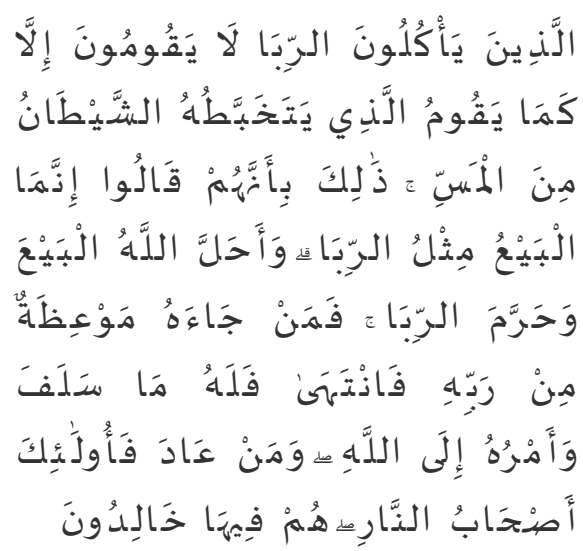

Orang-orang yang makan (mengambil) riba tidak dapat berdiri melainkan seperti berdirinya orang yang kemasukan syaitan lantaran (tekanan) penyakit gila. Keadaan mereka yang demikian itu, adalah disebabkan mereka berkata (berpendapat), sesungguhnya jual beli itu sama dengan riba, padahal Allah telah menghalalkan jual beli dan mengharamkan riba. Orangorang yang telah sampai kepadanya larangan dari Tuhannya, lalu terus berhenti (dari mengambil riba), maka baginya apa yang telah diambilnya dahulu (sebelum datang larangan); dan urusannya (terserah) kepada Allah. Orang yang kembali (mengambil riba), maka orang itu adalah penghunipenghuni neraka; mereka kekal di dalamnya."

Menurut Ibnu Katsir ayat ini berbicara bahwasannya Allah Swt. memberikan pengetahuan tentang orang-orang yang memakan riba dan memakan harta orang 
lain dengan cara yang batil, serta melakukan berbagai macam syubhat. Allah Swt. Menjelaskan bagaimana keadaan mereka pada saat dibangkitkan dan keluar dari kuburnya pada hari akhir. Ibnu Abbas mengatakan, sesungguhnya orang yang memakan riba dibangkitkan pada hari kiamat nanti dalam keadaan gila dan tercekik/Adapun kata al-mau'iz̧at pada ayat ini dimaknai dengan laranga. Hal ini bisa dilihat saat Ibnu Katsir memahami kalimat sebagai larangan memakan riba.

Kemudian menurut Quraish Shihab dalam tafsir al misbah dijelaskan term almau'izat yang bermakna peringatan yang Allah berikan kepada pelaku riba agar berhenti melakukan praktik riba, maka baginya apa yang telah diambil dahulu sebelum datang larangan, dan urusannya kembali kepada Allah. Sungguh Allah Maha kasih dan Maha bijaksana. Adapun yang kembali bertransaksi riba setelah peringatan itu datang maka orang ini adalah penghuni-penghuni neraka, mereka kekal di dalam neraka itu.

Nasihat tidak hanya diberikan kepada orang-orang yang menyimpang. Saat metode al-mau'izat dikaitkan dengan metode pendidikan maka perbuatan baik bisa diterapkan dan perbuatan buruk pun akhirnya hilang karena sudah adanya peringatan terlebih dahulu.

\section{Surah Al-Imran Ayat 138}

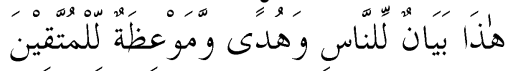

"Inilah (Alquran) suatu keterangan yang jelas untuk seтua manusia, dan menjadi petunjuk serta pelajaran bagi orang-orang yang bertakwa."

Ibnu Katsir menjelaskan bahwasannya Allah Swt. berfirman: Qur'an) ini adalah penerangan bagi seluruh manusia. Dengan mengabarkan bahwa di dalam Al-Qur'an terdpat penjelasan berbagai hal secara jelas, selain itu juga menjelaskan keadaan umat-umat terdahulu dan juga membahas keadaan musuh-musuh mereka. ووَهُدَى وَمَوْعِظة dan petunjuk serta pelajaran. Disini dipahami bahwa di dalam Al-Qur'an terdapat berita yang dapat dijadikan sebagai pengetahuan untuk kita tentang umat-umat sebelum kalian, petunjuk bagi hati kalian, sekaligus pelajaran agar tercegah dari hal-hal yang diharamkan dan semua perbuatan dosa. Berarti jelas bahwasannya al-mau'iz̧at pada ayat ini sebagai pelajaran.

Namun menurut Quraish Shihab dalam tafsir al-Mishbah, ayat ini, memerintahkan untuk mempelajari sunnah, yakni kebiasaan-kebiasaan atau ketetapan Ilahi dalam masyarakat. Sunnatullah adalah kebiasaan-kebiasaan Allah dalam memperlakukan masyarakat. Menurut tafsir 
ini juga bahwa juga ayat ini mengandung makna bahwa Allah tidak menjatuhkan sanksi sebelum manusia mengetahui sanksi itu. Dia tidak mendadak manusia dengan siksa-Nya, karena ini adalah penjelasan petunjuk jalan lagi peringatan.

Jadi sangat tepat metode ini diterapkan di dalam dunia Pendidikan, karena pada hakikatnya manusia sangat membutuhkan pelajaran yang dapat diambilnya dari suatu peristiwa disebabkan manusia memiliki alat pendengaran dan penglihatan untuk memahami kejadian.

4. Surah Al-Maidah Ayat 46

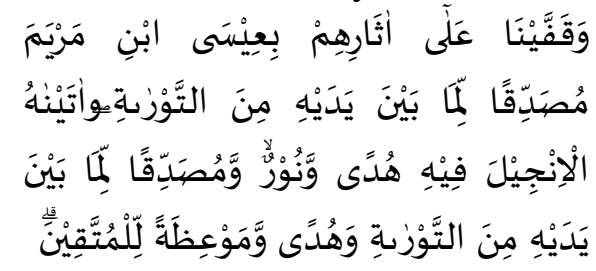

"Dan Kami teruskan jejak mereka dengan mengutus Isa putra Maryam, membenarkan Kitab yang sebelumnya, yaitu Taurat. Dan Kami menurunkan Injil kepadanya, di dalamnya terdapat petunjuk dan cahaya, dan membenarkan Kitab yang sebelumnya yaitu Taurat, dan sebagai petunjuk serta pengajaran untuk orang-orang yang bertakwa".

Menurut Ibnu Katsir saat menafsirkan

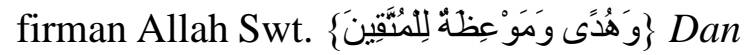
menjadi petunjuk serta pengajaran untuk orang-orang yang bertakwa." Bahwa Allah telah jadikan kitab Injil sebagai petunjuk yang dijadikan pegangan dan sebagai pengajaran, yakni peringatan untuk menjauhi perbuatan-perbuatan yang diharamkan dan perbuatan-perbuatan yang berdosa; bagi orang-orang yang bertakwa, yakni bagi orang-orang yang bertakwa kepada Allah dan takut kepada ancaman dan hukuman-Nya.

Kemudian Quraish Shihab dalam tafsir Al-Mishbah menjelaskan bahwasannya ayat ini menegaskan bahwa Setelah Allah mengutus nabi-nabi itu, Allah mengutus 'Isa putra Maryam kepada mereka agar mereka juga mempercayai Tawrat yang diturunkan sebelum mereka itu. Injil ini diturunkan kepada isa dengan mengandung petunjuk kepada kebenaran dan keterangan tentang hukum. Di samping itu, pada kitab Injil ini juga memberikan pembenran terhadap Tawrat yang diturunkan sebelumnya yang mengandung petunjuk dan pelajaran bagi orang-orang yang bertakwa. Pada ayat ini sudah jelas bahwasannya al-mau'izat dimaknai sebagai pelajaran juga sama seperti ayat sebelumnya.

\section{Surah Al-A'raf Ayat 145}

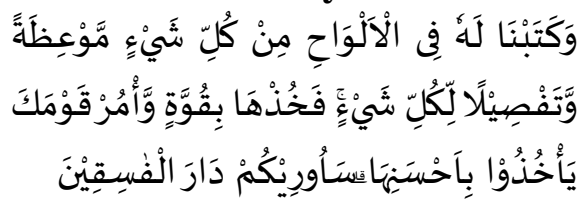

"Dan telah Kami tuliskan untuk Musa pada lauh-lauh (Taurat) segala sesuatu sebagai pelajaran dan penjelasan untuk segala hal; maka (Kami berfirman), 
"Berpegang teguh lah kepadanya dan suruhlah kaummu berpegang kepadanya dengan sebaikbaiknya, Aku akan memperlihatkan kepadamu negeri orang-orang fasik."

Ibnu Katsir menjelaskan bahwa disini Allah Swt. menceritakan bahwa Allah Swt menuliskan untuk Musa di dalam alwah (kitab Taurat) segala sesuatunya sebagai pelajaran dan keterangan bagi segala sesuatu. Menurut suatu pendapat, alwah tersebut dari pertama dan di dalamnya Allah Swt. menuliskan di dalamnya semua pelajaran dan hukum-hukum yang terinci menerangkan tentang halal dan haram. Dan alwah tersebut di dalamnya tercakup isi kitab Taurat yang disebutkan oleh Allah Swt. melalui firman-Nya. وَلَقَّْ آنَنَنَا مُوسَىَ

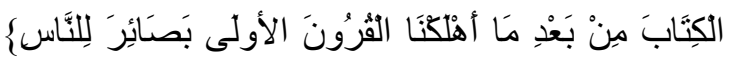
Dan sesungguhnya telah Kami berikan kepada Musa Al-Kitab (Taurat) sesudah Kami binasakan generasi-generasi yang terdahulu, untuk menjadi pelita bagi manusia. (Al-Qashash: 43).

Menurut suatu pendapat, alwah itu diberikan kepada Musa sebelum dia menerima kitab Taurat. Pada garis besarnya alwah tersebut merupakan pengganti bagi Musa dari permohonan yang dia mintakan untuk dapat melihat Allah, lalu Allah Swt melarangnya.
Namun Quraish Shihab menjelaskan di dalam tafsir al-Mishbah, bahwa ayat ini terdapat risalah Allah juga dijelaskan kalam Allah kepada Nabi Musa as. Hal ini bisa dilihat pada kalimat "dan telah Kami tuliskan untuknya, yakni untuk Musa as. Taurat ini di dalamnya terdapat segala sesuatu yang dibutuhkan oleh Bani Isra'il pada masa itu sebagai pelajaran dan penjelasan bagi segala sesuatu di dalam kehidupan dunia ini. Ayat ini menjelaskan bahwa "Kami berfirman kepada Musa as. ambillah ia, yakni berpeganglah teguhlah kepadanya dan suruhlah kaummu mengambil yang terbaik darinya, yakni suruhlah mereka melaksanakan kandungannya sebaik mungkin". Jadi disini terasa bahwa pada saat itu seperti ada yang bertanya: "Apakah ada yang akan mengabaikan yang terbaik atau petunjuk itu?" Terdengar jawaban: "Ada, yaitu orang-orang fasik", kemudian dilanjutkan bahwa, nanti akan Aku perlihatkan kepada kamu negeri tempat tinggal orang-orang yang fasik, antara lain kota suci al-Qudus, tempat tinggal musuh-musuh Bani Isra'il ketika itu, yakni orang-orang Kan'an atau negeri umat-umat yang telah diuraikan kisah kebinasaannya pada ayat-ayat yang lalu. 


\section{Surah Yunus Ayat 57}

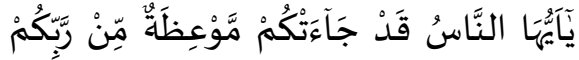

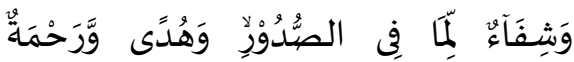

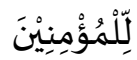

"Wahai manusia! Sungguh, telah datang kepadamu pelajaran (AlQur'an) dari Tuhanmu, penyembuh bagi penyakit yang ada dalam dada dan petunjuk serta rahmat bagi orang yang beriman."

Ibnu Katsir menjelaskan bahwasannya disini Allah berfirman, memberikan karunia kepada makhluk-Nya yaitu berupa alQur'an yang Agung, yang Allah turunkan

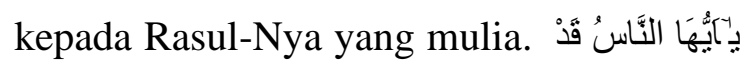

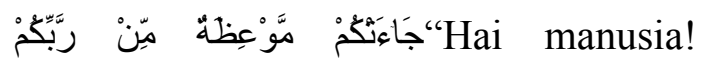
Sesungguhnya telah datang kepadamu pelajaran dari Rabbmu." Maksudnya pencegah kekejian.

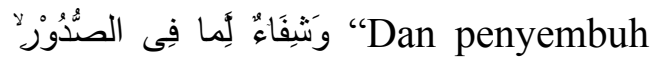
bagi penyakit-penyakit (yang berada) dalam dada." Maksudnya, dari kesamarankesamaran dan keraguan-keraguan, yaitu menghilangkan kekejian dan kotoran di dalamnya.

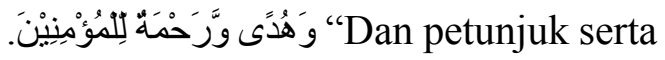
rahmat. bagi orang yang beriman." Maksudnya, hidayah dan rahmat dari Allah Ta'ala dapat dihasilkan dengan adanya alQur'an itu. Dan sesungguhnya hidayah dan rahmat itu hanyalah untuk orang-orang yang beriman kepadanya, membenarkan dan menyakini apa yang ada di dalamnya,

Menurut Quraish Shihab dalam tafsir al-Mishbah, bahwa ayat ini menyampaikan fungsi wahyu yang mereka ingkari dan lecehkan itu. Wahai seluruh manusia, di mana dan kapan pun sepanjang masa, sadarilah bahwa sesungguhnya telah dating kepada kamu semua pengajaran yang sangat agung dan bermanfaat dari Tuhan Pemelihara dan Pembimbing kamu yaitu alQur'an al-Karim dan obat yang sangat ampuh bagi apa, yakni penyakit-penyakit kejiwaan yang terdapat dalam dada, yakni hati manusia dan petunjuk yang sangat jelas menuju kebenaran dan kebajikan serta rahmat yang amat besar lagi melimpah bagi orang-orang mukmin.

Kata مَوْعِظة terambil dari kata (وعظة ) waazha yaitu "peringatan menyangkut kebaikan yang menggugah hati serta menimbulkan rasa takut." Peringatan itu oleh ayat ini ditegaskan bersumber dari Allah swt. yang merupakan (رَبِّمْ ) rabbikum, yakni Tuhan Pemelihara kamu. Dengan demikian, pastilah tuntunan-Nya sempurna, tidak mengandung kekeliruan lagi sesuai dengan sasaran yang dituju.

Quraish shihab mengatakan di dalam tafsir ini, bahwa ayat ini menegaskan bahwa Alquran adalah obat bagi apa yang terdapat dalam dada. Penyebutan kata dada yang 
diartikan dengan hati, menunjukkan bahwa wahyu-wahyu llahi itu berfungsi menyembuhkan penyakit-penyakit ruhani seperti ragu, dengki, takabur dan semacamnya. Memang, oleh Alquran hati ditunjuknya sebagai wadah yang menampung rasa cinta dan benci,'berkehendak dan menolak. Bahkan hati dinilai sebagai alat untuk mengetahui. Hati juga yang mampu melahirkan ketenangan dan kegelisahan serta menampung sifat-sifat baik dan terpuji.

\section{Surah Huud Ayat 120}

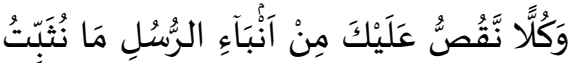

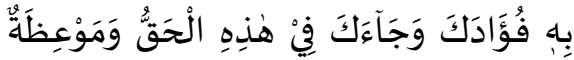

$$
\begin{aligned}
& \text { وَّذِكْرَى لِلْمُمُوْمِنِيْنَ }
\end{aligned}
$$

Allah berfirman, Kami kabarkan seluruh kisah kepadamu, dari berita-berita para Rasul yang terdahulu sebelummu bersama umat-umatnya dan bagaimana perdebatan dan pertentangan yang terjadi pada mereka, pendustaan juga siksaan yang dirasakan oleh para Nabi dan bagaimana Allah menolong pasukan-Nya, orang-orang yang beriman dan merendahkan musuhmusuh-Nya yang kafir. Semua ini adalah termasuk sesuatu yang Kami buat hatimu teguh. Maksudnya, menjadikan keteguhan dalam hatimu ya Muhammad dengan berita-berita itu, agar menjadi contoh bagimu dari kisah saudaramu para Rasul yang telah lalu.

Dan firman-Nya: وَجَاءَكَ فِيْ هلدِِ الحَقُ "Dan dalam surat ini telah datang kepadamu kebenaran," maksudnya, dalam kebenaran ini ialah, dalam surat ini. Ini adalah perkataan Ibnu `Abbas, Mujahid dan ulama salaf. Telah datang kepadamu kisahkisah yang sesungguhnya dan berita yang benar, juga nasihat yang membuat orangorang kafir terpukul dan peringatan yang harus diingatkan oleh orang-orang yang beriman.

Di dalam tafsir al-Mishbah, bahwa ayat inilah penutup dari kisah-kisah dan surah Huud yang menyimpulkan uraian-uraian yang lalu. Ia menjelaskan tujuan penyampaian kisah rasul-rasul, bagi Nabi Muhammad saw., umatnya dan mereka yang tidak percaya. Demikian juga tujuan kehadiran tuntunan-tuntunan llahi yang disampaikan kepada beliau melalui alQur'an serta kata akhir menyangkut orangorang yang tidak percaya kepada kitab suci itu yang ayat-ayatnya disusun dengan rapi, kemudian dijelaskan secara terperinci. (Baca ayat pertama surah ini). 
Untuk kisah-kisah yang telah disampaikan dalam surah ini bahkan wahyu-wahyu yang lalu, ayat ini menegaskan bahwa dan semua kisah yang Kami kisahkan kepadamu, wahai Muhammad, sekarang dan akan datang demikian juga yang telah lalu dan juga berita-berita penting para rasul bersama umat mereka, baik yang taat maupun yang durhaka apayang dengannya Kami teguhkan hatimu guna menghadapi tugastugas berat yang dibebankan kepadamu dan bertambah yakinlah bahwa telah datang kepadamu di sini, yakni dalam surah atau kitab suci ini kebenaran mutlak yang sempurna, seperti tentang keesaan Allah dan keniscayaan hari Kemudian serta terdapat juga di dalamnya pengajaran yang sangat berharga dan peringatan bagi orangorang mukmin.

\section{Surah An-Nahl Ayat 125}

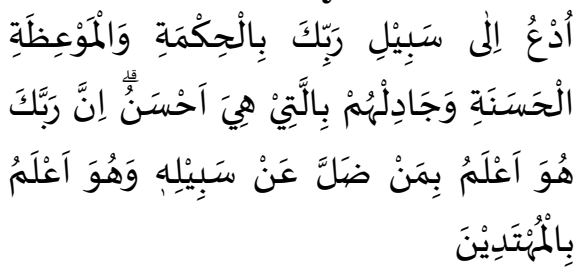

"Serulah (manusia) kepada jalan Tuhanmu dengan hikmah dan pengajaran yang baik, dan berdebatlah dengan mereka dengan cara yang baik. Sesungguhnya Tuhanmu, Dialah yang lebih mengetahui siapa yang sesat dari jalan-Nya dan Dialah yang lebih mengetahui siapa yang mendapat petunjuk."
Tafsir Ibnu katsir menjelaskan bahwasannya pada ayat ini Allah Swt. memerintahkan kepada Rasul-Nya Muhammad Saw. agar menyeru manusia untuk menyembah Allah dengan hikmah (cara yang bijaksana). Hal ini sesuai dengan yang disampaikan oleh Ibnu Jarir bahwa telah diajarkan oleh Nabi Muhammad berupa Alquran, Sunnah, dan pelajaran yang baik; maka di dalamnya terdapat larangan-larangan dan berbagai kejadian yang menimpa manusia (di masa lalu). Setelah melihat itu timbullah ikhtibar agar mereka waspada akan siksa Allah Swt. (terhadap mereka yang durhaka). Pada ayat ini juga Allah Swt. memerintahkan Nabi Saw. untuk bersikap lemah lembut, seperti yang Allah perintahkan kepada Musa dan Harun, ketika mereka berdua diutus oleh Allah Swt. kepada Fir'aun. Setelah ada ayat yang lalu Nabi Muhammad saw. telah diperintahkan untuk mengikuti Nabi Ibrahim as. maka ayat ini memerintahkan lagi untuk mengajak manusia untuk Kembali mengikuti pula prinsip-prinsip ajaran Tauhid yang telah dikumandangkan oleh Nabi Ibrahim terdahulu.

Namun dalam tafsir al-Mishbah, Quraish Shibab menyatakan bahwa ayat ini dipahami oleh sementara ulama sebagai menjelaskan tiga macam metode dakwah yang harus disesuaikan dengan sasaran 
dakwah. Adapun cendekiawan yang memiliki pengetahuan tinggi diperintahkan menyampaikan dakwah dengan hikmah yakni berdialog dengan kata-kata bijak sesuai dengan tingkat kepandaian mereka. Terhadap kaum awam, diperintahkan untuk menerapkan al-mau 'izat yakni memberikan nasihat dan perumpamaan yang menyentuh jiwa sesuai dengan taraf pengetahuan mereka yang sederhana. Sedang terhadap Ahl al-Kitab dan penganut agama-agama lain yang diperintahkan adalah jidal/perdebatan dengan cara yang terbaik yaitu dengan logika dan retorika yang halus, lepas dari kekerasan dan umpatan.

Quraish Shihab menjelaskan bahwa pada ayat ini al-mau'izat terambil dari kata ) ( وعظ ( 'azha yang berarti nasihat. Almau'izat adalah uraian yang menyentuh hati yang mengantar kepada kebaikan. Demikian dikemukakan oleh banyak ulama. Sedang kata ( ) jadilhum terambil dari kata ( ) jidal yang bermakna diskusi atau buktibukti yang mematahkan alasan atau dalih mitra diskusi dan menjadikannya tidak dapat bertahan, baik yang dipaparkan itu diterima oleh semua orang maupun hanya oleh mitra bicara.

Al-mau'iz̧at hendaknya disampaikan dengan hasanah / baik, sedang perintah ber jidal disifati dengan kata ahsan / yang terbaik, bukan sekadar yang baik.
Keduanya berbeda dengan hikmah yang tidak disifati oleh satu sifat pun. Ini berarti bahwa al-mau'izat ada yang baik dan ada yang tidak baik, sedang jidal ada tiga macam, yang baik, yang terbaik, dan yang buruk.

\section{Surah An-Nur Ayat 34}

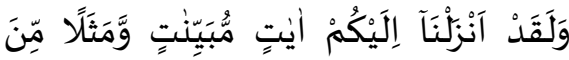

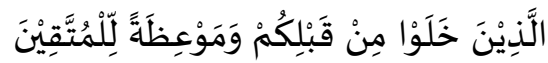

Menurut Ibnu Katsir bahwasannya

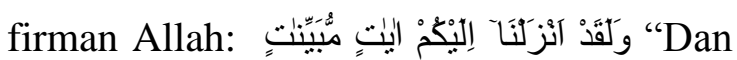
sesungguhnya Kami telah menurunkan kepadamu ayat-ayat yang memberikan penerangan,” ) yakni, Alquran berisi ayatayat yang jelas dan memberi penerangan

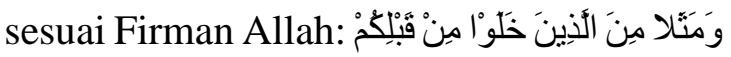
"Dan contoh-contoh dari orang-orang terdahulu sebelumnya.") yakni kabar-kabar dari umat terdahulu dan adzab yang menimpa mereka karena menyelisihi perintah-perintah Allah, seperti yang disebutkan dalam ayat lain: فَجَعَنَاهُمْ سَلَفًا وَمَتَّلا Dan Kami jadikan mereka sebagai pelajaran dan contoh bagi orang-orang yang kemudian.”) (az-Zukhruf: 56). Sebagai peringatan agar kalian tidak melakukan perbuatan dosa dan perbuatan haram. 
Sومَوْعِظة للِمَنَفِقِينَ "Dan pelajaran bagi orang-orang yang bertakwa." yakni bagi orang-orang yang bertakwa dan takut kepada Allah.

Sedangkan dalam tafsir al-Mishbah, bahwa ayat ini menjadi penutup dari uraian ayat yang membahas mengenai isu yang menimpa keluarga Nabi Muhammad saw. dan juga petunjuk-petunjuk mengenai isu tersebut. Hal ini juga bisa dikaitkan dengan ayat pertama dari surah an-Nur. Allah telah menurunkan surah an-Nur dan juga surah yang lainnya dengan terang dan jelas juga sambal memberikan penerangan dalam berbagai tuntutan hidup. Alquran juga menampilkan contoh-contoh serupa dengan yang dialami oleh ihwalnya orang-orang masa lalu. Seperti ihwalnya Maryam as.yang dituduh berzina atau misalnya kisah nabi Yusuf yang dituduh berselingkuh. Ayat ini juga memberikan nasehat yang menyeluruh dan pelajaran bagi mereka yang membuka pikiran dan hatinya yakni mereka itulah orang yang bertakwa.

Berdasarkan yang penulis kutip mengenai makna al-mau'iz̧at di dalam surah al-Baqarah ayat 66 dan 275, lalu pada surah Ali Imran: 138, al-Maidah: 46, alAraf: 145, Yunus: 57, Hud: 120, an-Nahl: 125, an-Nur: 34. mufassir mendefinisikan kata-kata al-mau'iz̧at dengan kata-kata yang mengandung nasihat yang bagus, tidak menyakiti dan menakut-nakuti. Ada juga pada ayat-ayat tersebut yang ditafsir sebagai pelajaran dan juga al-mau'izat ini ditafsirkan dengan kata peringatan. Karena Ibnu Katsir, ketika menafsirkan surat alBaqarah:66 mengatakan bahwa yang dimaksud dengan al-mau'izat adalah peringatan keras. Namun pada surah anNur, Ibnu Katsir mendefenisikan almau'izat sebagai pelajaran bagi orang yang bertakwa.

Berbeda dengan Qurasih Shihab saat menafsirkan surah an-Nahl ayat 125 bahwa kata مَوْغِظة terambil dari kata ( وعظة ) waazha yaitu "peringatan menyangkut kebaikan yang menggugah hati serta menimbulkan rasa takut." Peringatan itu oleh ayat ini ditegaskan bersumber dari Allah swt. yang merupakan (رَبِّمْن ) rabbikum, yakni Tuhan Pemelihara kamu. Dengan demikian, pastilah tuntunan-Nya sempurna, tidak mengandung kekeliruan lagi sesuai dengan sasaran yang dituju. Quraish shihab mengatakan di dalam tafsir ini, bahwa ayat ini menegaskan bahwa Alquran adalah obat bagi apa yang terdapat dalam dada. Penyebutan kata dada yang diartikan dengan hati,

Saat mengaitkan makna al-mau'iz̧at yang telah ditafsirkan oleh mufassir kedalam dunia Pendidikan, bahwa seorang pendidik bisa menggunakan metode al- 
mau'izat ini di dalam berjalannya proses pendidikan, khususnya pendidikan Islam. Seorang pendidik (guru) tidak hanya memberikan nasehat yang baik saja saat mengajar kepada peserta didik. Karena tidak semua peserta didik busa menerima nasehat yang baik. Terkadang ada juga peserta didik yang butuh diberikan peringatan agar jangan sampai melakukan kesalahan yang berulang-ulang. Seorang guru memiliki kewajiban untuk melarang dan memberikan peringatan kepada peserta didiknya agar tidak melakukan hal kebukurukan lagi. Hal ini dilakukan dengan tujuan agar mereka sadar dan memperbaiki pemahaman yang salah selama ini. Peran guru sebagai pendidik untuk selalu membimbing dan meluruskan siswa jika melakukan keburukan.dan juga ada juga peserta didik yang butuh diberikan kisahkisah masa lampau yang bisa diambil oleh mereka sebagai pelajaran agar lebih berhatihati dalam menjalankan hidup di dunia ini.

Konsep al-mau'izat ini sangat cocok diberikan pada peserta didik agar mereka bisa taat pada peraturan yang telah ditetapkan dan juga agar mereka selalu mendengarkan apa yang diperintahkan oleh guru. Seperti yang kita ketahui bahwasannya guru yang berperan sebagai pendidik dalam ruang lingkup pendidikan. Apabila mereka tidak mendengarkan apa yang telah dinasihatkan, maka mereka sedang memperolok-olok guru mereka sebagai pendidik. Apa yang dinasihatkan guru menjadi pembelajaran yang baik bagi mereka. Dengan mematuhi apa yang diperintahkannya, maka akan menjadikan siswa taat pada peraturan dan tidak mencoba untuk melanggar ketetapanketetapan guru maupun sekolah.

Perlu diketahui juga bahwa seperti yang sudah dijelaskan sebelumnya bahwa manusia sangat membutuhkan nasihat. Dengan demikian metode ini cocok ditujukan untuk kepada semua siswa. Sebagai siswa harus bijaksana mendengarkan nasihat-nasihat yang diberi gurunya. Maksud bijaksana disini yaitu menyaring apa-apa yang telah dinasihatkan. Begitu pula dengan guru harus pandai memberikan nasehat kepada muridnya. Jika ada kata atau nasihat yang tidak baik, maka tinggalkanlah, ambil apa yang baik sebagaimana yang telah dinasihatkan.

\section{KESIMPULAN}

Makna al-mau'izat di dalam surah alBaqarah ayat 66 dan 275, lalu pada surah Ali Imran: 138, Al-Maidah: 46, Al-Araf: 145, Yunus: 57, Hud: 120, An-Nahl: 125, an-Nur: 34. mufassir mendefinisikan katakata al-mau'izat dengan kata-kata yang mengandung nasihat yang bagus, tidak menyakiti dan menakut-nakuti. Ada juga 
pada ayat-ayat tersebut yang ditafsir sebagai pelajaran dan juga al-mau'izat ini ditafsirkan dengan kata peringatan.

Saat mengaitkan makna al-mau'izat yang telah ditafsirkan oleh mufassir kedalam dunia Pendidikan, bahwa seorang pendidik bisa menggunakan metode almau'izat ini di dalam berjalannya proses pendidikan, khususnya pendidikan Islam. Seorang pendidik (guru) tidak hanya memberikan nasehat yang baik saja saat mengajar kepada peserta didik. Karena tidak semua peserta didik busa menerima nasehat yang baik. Terkadang ada juga peserta didik yang butuh diberikan peringatan agar jangan sampai melakukan kesalahan yang berulang-ulang.

\section{DAFTAR PUSTAKA}

Al-Ashfahani, Ar-Raghib. (2017). Kamus Al-Quran terj. Ahmad Zaini Dahlan, Jilid 3. Depok: Pustaka Khazanah Fawa'id.

Al-Baqi', Muhammad Fu'ad Abdul (1998). Al-Mu'jam Al-Mufahras li Al-Faz AlQur'an Al-Karim. Qahirah: Dar AlHadis.

Al-Farmawy, Al-Hayy. (1996). Metode Tafsir Mawdhu'iy. Jakarta: PT RajaGrafindo Persada.

Eriyanto. (2011). Analisis Isi. Jakarta: Kencana Media Group.

Fadhlullah. Muhammad Husain. (1997). Metodologi Dakwah dalam Al-Qur'an. Jakarta: Lentera.

Hakim, M. Baqir. (2006). Ulumul Quran. Jakarta: Al-Huda.
Ibnu Katsir. (2004). Tafsir Ibnu Katsir Jilid 1 terj. M. Abdul Ghafar, dkk, et al. Bogor: Pustaka Imam Syafi'i.

Katsir, I. et.al. (2004). Tafsir Ibnu Katsir Jilid 2. Bogor: Pustaka Imam Syafi'i.

Katsir, I. et.al. (2004). Tafsir Ibnu Katsir Jilid 3. Bogor: Pustaka Imam Syafi'i.

Katsir, I. et.al. (2004). Tafsir Ibnu Katsir Jilid 4. Bogor: Pustaka Imam Syafi'i.

Katsir, I. et.al. (2004). Tafsir Ibnu Katsir Jilid 5. Bogor: Pustaka Imam Syafi'i.

Katsir, I. et.al. (2004). Tafsir Ibnu Katsir Jilid 6. Bogor: Pustaka Imam Syafi'i.

Krippendorf, Klaus. (1991). Analisis Isi Pengantar Teori dan Metodologi. Jakarta: Rajawali Pers.

Shihab, M.Q. (2002). Tafsir Al Mishbah: Pesan, Kesan dan Keserasian Alquran, Jilid 1. Jakarta: Lentera Hati.

Shihab, M.Q. (2002). Tafsir Al Mishbah: Pesan, Kesan dan Keserasian Alquran, Jilid 2. Jakarta: Lentera Hati.

Shihab, M.Q. (2002). Tafsir Al Mishbah: Pesan, Kesan dan Keserasian Alquran, Jilid 3. Jakarta: Lentera Hati.

Shihab, M.Q. (2002). Tafsir Al Mishbah: Pesan, Kesan dan Keserasian Alquran, Jilid 6. Jakarta: Lentera Hati.

Shihab, M.Q. (2002). Tafsir Al Mishbah: Pesan, Kesan dan Keserasian Alquran, Jilid 7. Jakarta: Lentera Hati.

Soehartono, I. (1999). Metode Penelitian Sosial. Bandung: PT Remaja Rosdakarya.

Sugiyono. (2007). Metode Penelitian Kuantitatif Kualitatif dan $R$ \& $D$. Bandung: Alfabeta.

Suryabrata, S. (1983). Metodologi Penelitian. Jakarta: CV Rajawali 